\title{
Marketing Channels and Post Harvest Practices of Onion: A Case of Bogra and Joypurhat District in Bangladesh
}

\author{
K. M. Mehedi Adnan,", Md. Mostafizur Rahman², Swati Anindita Sarker ${ }^{3}$ \\ ${ }^{1}$ Department of Agricultural Finance \& Banking, Sylhet Agricultural University \\ ${ }^{2}$ Department of Agricultural Marketing \& Business Management, Sylhet Agricultural University \\ ${ }^{3}$ Department of Agricultural Economics, Bangladesh Agricultural University \\ *Corresponding Author: mehedi_adnan@yahoo.com
}

Copyright $@ 2014$ Horizon Research Publishing All rights reserved.

\begin{abstract}
The study was undertaken to analyze the marketing system and post harvest practices of onion both at farmers and trades level. Four marketing channels were identified in onion marketing. The study indicated that longer marketing channel gave lesser share to farmer than shorter channel. The study indicated that shorter channel showed less marketing loss and longer channel it was high. High price gap was found between farmers and consumers level. The intermediaries sorted decayed and removed the outer loose shell of onion before marketing. Proper scientific method for post-harvest practices and co-operative market \& market monitoring facility should be introduced by government.
\end{abstract}

Keywords Marketing Channel, Post Harvest and Onion

\section{Introduction}

Bangladesh is a densely populated agrarian country where agriculture contributes 19.29 percent to the Gross Domestic Product (GDP) and providing employment for 45.4 per cent of the population. Approximately 11 percent of the GDP is derived from crops [1]. The Government of Bangladesh has taken programme towards diversifying agriculture and has placed special emphasis on the development of minor crops under crop diversification program. Onion is one of the most important crops among the vegetables and spices in Bangladesh both in acreage and production and rank first among the spices grown in the country [2]. Onion is one of the most important crops among the vegetables and spices in Bangladesh both in acreage and production and rank first among the spices grown in the country [2]. It is to consume either as spice or as condiment. The crop is grown in 1.25 lakh hectares of land with an annual production of 8.89 lakh metric tons [3] . Onion is semi perishable crop and subject to deterioration during storage, transportation and marketing. However, with an increasing population of the country, the demand of onion is also increasing day by day which triggered the scientists to improve cultivation method for higher productivity, modern storage technique and marketing system.

In a study [4] it is found that farmers sold over two-third of onion just after harvest to the local traders in village market. Sabur [5] revealed that the storage facilities for spices particularly cold storage were limited and the seasonal price variation largely dependent on the perish ability of spices. Raha [6] showed the significant seasonal price fluctuation of onion in Bangladesh. Onion is popular crop to the farmer for its higher demand and price, diversified use, favorable potentiality to grow the soils and agro-climatic condition in Bangladesh. Not only has this but also in net return of onion occupied good position among all other crops. But there is a wide variation in price between producer and consumers level at harvesting period. It occurs due to marketing systems. A good marketing system is very important to ensure supply from farmers to consumers in time. It is however, necessary to quantify post harvest practices at different intermediaries' level, marketing channel and identify constraints existed in the onion marketing system in Bangladesh. With this end in view, the present study was undertaken. The findings of the study undoubtedly important to a businessman, farmers as well as to the policy makers for planning future production, import, export, price stabilization measures etc.

The objectives were:

- To find out the different channels of onion marketing from grower to consumers;

- To determine the marketing cost, margin and profit of farmers and intermediaries in the marketing system;

- To identify the post harvest practices of different intermediaries and losses in different channels.

\section{Materials and Methods}

Onion obtained from two sources was marketed in our country; one is indigenous production and the other was imported. The study was conducted in respect of only 
indigenous production of onion. Two important onion growing districts namely Bogra and Joypurhat were purposively selected for the study. A total of fourty farmers taking twenty from each area were selected randomly. Four onion markets were selected purposively taking one primary and one secondary market from each district for the study. Sixty intermediaries were chosen randomly from two primary markets taking fifteen intermediaries (10 pharias, 10 wholesalers and 10 rural retailers) from each market. On the other hand, thirty intermediaries were randomly select from four secondary /terminal markets taking fifteen intermediaries (10 wholesaler, 10 aratders and 10 urban retailers) from each market. Two sets of pre tested interview schedules; one for farmers and the other for intermediaries were used for the collection of data/ information using survey method. Marketing margin was calculated by deducting purchase price from sale price, while the profit was difference between marketing margin and marketing cost. Aratdar was not taken into consideration in calculating margin and profit because they act as a commission agent. Tabular method using average, percentage, ratios etc. was followed in analyzing the results of the study.

\subsection{Results and Discussion}

Marketing channel refers to the sequential arrangements of various marketing intermediaries involved in the movement of products from producers to consumers. Onion moves from farmers to ultimate consumers through a number of marketing channels. A number of intermediaries like pharia, wholesaler, aratdar and retailer were involved in onion marketing. Four major channels of onion were identified in the study areas.

The channels are as follows

\begin{tabular}{|cc|}
\hline Channel -1 & $\begin{array}{c}\text { Farmers }- \text { pharia }- \text { wholesaler }- \text { aratdar }- \\
\text { retailer }- \text { consumer }\end{array}$ \\
Channel -2 & Farmers - pharia - retailer - consumer \\
Channel -3 & Farmers - wholesaler - aratdar - retailer - \\
consumer \\
Channel -4 & Farmers - retailer - consumer \\
\hline
\end{tabular}

It was revealed from the study, 55 percent of produced onions were moved from farmers to consumer through the Channel- 1 and 22 percent through Channel-3, respectively. One the other hand, 10 and 13 percent onion moved respectively through Channel-2 and Channel-4 (Figure 1).

\subsection{Marketing Cost of Onion}

Marketing cost represents the cost of performing various marketing functions, which are required to transfer a commodity from the place of production to the ultimate consumers [7]. The marketing cost of onion included the cost of transport, loading and unloading, gunny bag, commission, market tolls, bribery/subscription, storage, house fair, cleaning and grading, and others. The other cost were personal cost of traders, electricity cost etc. The marketing cost of farmers was Tk. 1535/ton (Table-1). The marketing cost of pharia was Tk. 1349/ton. On the other hand marketing cost of wholesaler was Tk. 4001 and 5796 per ton of onion in secondary and terminal market respectively. While in retail market, it was Tk. 2769 and 3588 per ton in secondary and terminal markets receptively (Table1).

\subsection{Marketing Margins and Profits of Onion}

According to Kohls and Uhl [8] marketing margin is defined as the difference between what is paid by the consumers and what is received by the producers. Marketing margin of each intermediary was estimated by deducting the purchase price of onion from its sale price while the net profit was estimated by deducting marketing cost from the marketing margin.

Marketing margins of pharia was Tk. 6813 per ton, while it was Tk 10092 and 12087 per ton in secondary and terminal markets for wholesaler (Table-2). The marketing margins Tk. 13058 and 15240 were in secondary and terminal market for retailer. The margins were the highest for retailer compared to other intermediaries in both secondary and terminal markets. The profits were also found the highest for retailer both secondary and terminal market. Consequently, profit as percent of investment was highest also for retailer. The reasons the highest profit and margins were due to higher selling price of the onion.

\subsection{Post Harvest Practices of Onion at Different Intermediaries' Level}

Onion is semi perishable in nature. Post harvest technique reduces short term losses of onion. After harvesting, farmers cut the onion tops within 1.0 to $1.5 \mathrm{~cm}$ neck length. Top cutting bulbs significantly improve the storage quality of onion [9].Hundred percent of farmer in the survey areas followed this technique due to reduce decayed of onion. Most of the farmers ( 85 percent) cured onion bulbs in the shade for 2-3 days before storing or marketing. The farmer and other different intermediaries (i.e. pharia, wholesaler and retailer) sorted decayed bulb when the onion is started to decay. Hundred percent farmers and intermediaries were sorted decayed bulb before marketing. For the attraction of buyer some farmers and intermediaries removed the outer loose shell of onion before selling. Eighty five, 80, 90 and 100 percent of farmer, pharia, wholesaler and retailer respectively removed the outer loose shell of their onion before selling. The farmer used normal gunny bag for onion marketing but pharia, wholesaler and retailer used perforated gunny bag due to proper aeration. To reduce decaying of onion, the middlemen used fan in storage place. Forty five percent of wholesaler and 25 percent of retailer in secondary /terminal market blown air in onion lot by using table fan (Table 3). 

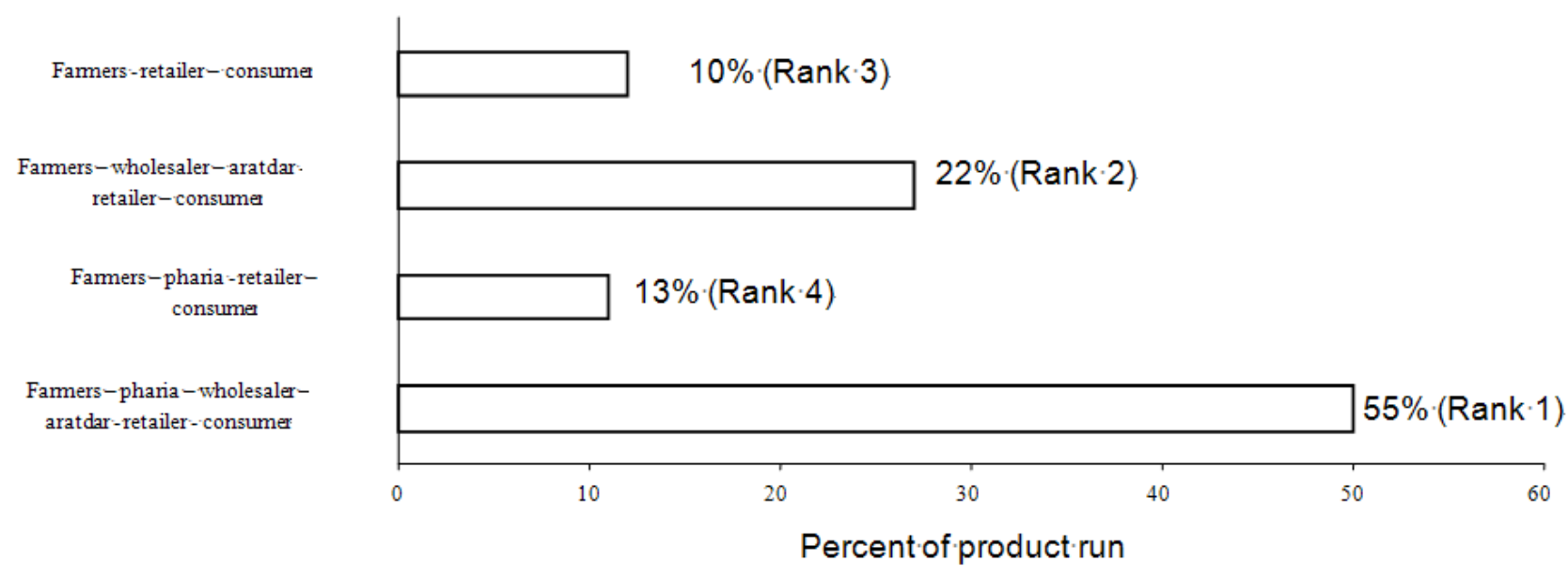

Figure 1. Marketing channels of onion with high Priority 
Table 1. Cost of marketing of onion by different intermediaries

\begin{tabular}{|c|c|c|c|c|c|c|c|c|c|c|c|}
\hline \multirow[b]{2}{*}{ Intermediaries } & \multicolumn{11}{|c|}{ Cost (Tk/ton) } \\
\hline & Transport & $\begin{array}{l}\text { Loading } \\
\text { and } \\
\text { unloading }\end{array}$ & $\begin{array}{c}\text { Gunny } \\
\text { bag }\end{array}$ & Commission & Market tolls & $\begin{array}{c}\text { Bribery/ } \\
\text { Subscription }\end{array}$ & $\begin{array}{c}\text { Storage } \\
\text { cost }\end{array}$ & House fair & $\begin{array}{l}\text { Cleaning } \\
\text { and grading }\end{array}$ & Others & Total \\
\hline Farmer & 252 & - & 86 & - & 158 & - & 787 & - & 158 & 94 & 1535 \\
\hline Pharia & 347 & 169 & 171 & - & 150 & - & - & 150 & 212 & 150 & 1349 \\
\hline \multicolumn{12}{|l|}{$\underline{\text { Wholesaler }}$} \\
\hline Secondary Market & 851 & 315 & 882 & 1260 & 0 & 150 & - & & 291 & 252 & 4001 \\
\hline Terminal market & 1733 & 472 & 882 & 1890 & 0 & 150 & - & & 354 & 315 & 5796 \\
\hline \multicolumn{12}{|l|}{$\underline{\text { Retailer }}$} \\
\hline Secondary Market & 252 & 221 & 169 & 1260 & 189 & 150 & - & 126 & 134 & 268 & 2769 \\
\hline Terminal market & 347 & 237 & 170 & 1890 & 221 & 150 & - & 126 & 165 & 282 & 3588 \\
\hline
\end{tabular}

Table 2. Marketing margin and profit of onion by different intermediaries level

\begin{tabular}{|c|c|c|c|c|c|c|}
\hline \multirow{2}{*}{ Intermediaries } & \multicolumn{5}{|c|}{$\mathrm{Tk} / \mathrm{ton}$} & \multirow{2}{*}{$\begin{array}{l}\text { Net profit as \% of } \\
\text { investment }\end{array}$} \\
\hline & Purchase price & Sale price & Cost of marketing & Marketing margin & Net profit & \\
\hline Farmer & - & 43455 & 1535 & - & - & - \\
\hline Pharia & 50737 & 57550 & 1349 & 6813 & 5464 & 10.77 \\
\hline \multicolumn{7}{|l|}{ Wholesaler } \\
\hline Secondary Market & 57390 & 67482 & 4001 & 10092 & 6091 & 10.62 \\
\hline Terminal market & 57390 & 69492 & 5796 & 12087 & 6291 & 10.96 \\
\hline \multicolumn{7}{|l|}{$\underline{\text { Retailer }}$} \\
\hline Secondary Market & 67237 & 80295 & 2769 & 13058 & 10289 & 15.30 \\
\hline Terminal market & 69372 & 84612 & 3588 & 15240 & 11652 & 16.80 \\
\hline
\end{tabular}


Table 3. Post- harvest practices of onion at different intermediaries' level

\begin{tabular}{|c|c|c|c|c|c|}
\hline $\begin{array}{l}\text { Sl. } \\
\text { No. }\end{array}$ & Particulars & Farmer & Pharia & Wholesaler & Retailer \\
\hline 1. & Neck cutting & $100 \%$ & - & - & - \\
\hline 2. & Curing in shade & $85 \%$ & - & - & - \\
\hline 3. & Sorting of decayed bulb & $100 \%$ & $100 \%$ & $100 \%$ & $100 \%$ \\
\hline 4. & Remove outer loose shell & $85 \%$ & $80 \%$ & $87 \%$ & $100 \%$ \\
\hline 5. & Bagging & Gunny bag & $\begin{array}{l}\text { Perforated gunny } \\
\text { bag }\end{array}$ & $\begin{array}{l}\text { Perforated } \\
\text { gunny bag }\end{array}$ & $\begin{array}{l}\text { Perforated } \\
\text { gunny bag }\end{array}$ \\
\hline 6. & Aeration & - & - & $45 \%$ & $25 \%$ \\
\hline
\end{tabular}

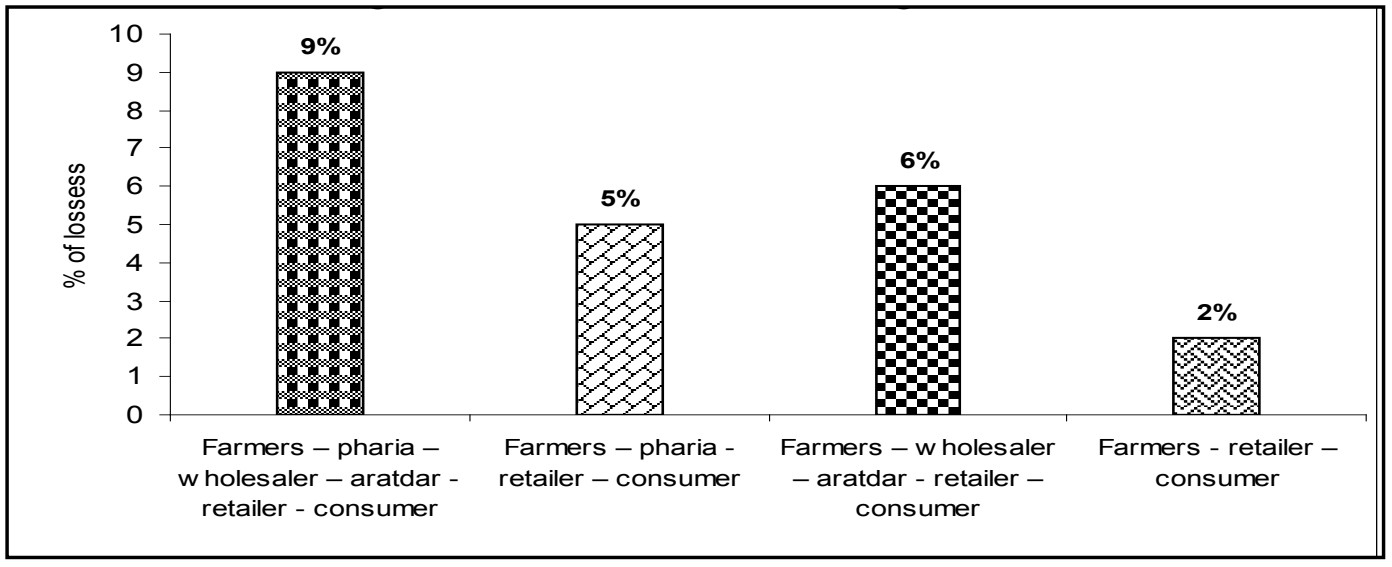

Figure 2. Losses in different marketing channel

\subsection{Losses of Different Marketing Channel}

Post harvest loss was also calculated on the basis of different marketing channels. It was found that the loss under each of Channel-1, Channel-2, Channel-3, and Channel-4 were $9,5,6$ and 2 percent respectively. It indicated that shorter channel had less and larger channels had more loss (Figure 2).

\section{Conclusions and Recommendation}

It may be concluded from the foregoing discussion that the production and marketing of onion were profitable to the farmers and intermediaries level. Large amount of profit share is going to whole sale and retail market and small amount of in producer level. In long run that may be discourse the producer level for production. So, storage facility and transport facility should be improved in producer level to cut marketing channel. Government should take necessary steps to check high price difference in different marketing channel for the betterment of farmer as well as consumer. Market taxes/tolls and other charges should be within the limits of the farmers and intermediaries. Small marketing channel ensure the small amount of losses. So, Co-operative marketing system in this sector should be developed to ensure better price of onion for the farmers. Proper scientific methods should be developed in harvesting and post-harvest handling operating of the onion to prevent the huge losses and to maintain the quality.

\section{REFERENCES}

[1] GoB (2012), Bangladesh Economic Review. Economic Division, Ministry of Finance, Government of the People's Republic of Bangladesh, Dhaka.

[2] Goswami, S.N. (1991). Price Spread of Tomato in a Village Market of Kamnep District, Asam. Journal of Agricultural Marketing. 34(4).

[3] BBS (2009), Statistical Yearbook of Bangladesh, Bangladesh Bureau of Statistics, Statistics Division, Ministry of Planning, Government of the People's Republic of Bangladesh, Dhaka.

[4] Hossain, A.H., M. Islam, T.H. Miah, S.A. Sabur, G. Rabbani, N. Islam, F. Ahmed and Kamrunnahar (2006). Annual Benefit, Monitoring and Evaluation Survey 2005, North West Crop Diversification Project. Oct. 2006.

[5] Sabur, S.A. and Mollah, (1993). Trend, Variability and Relative Profitability of Spices in Bangladesh. The Bangladesh Journal of Agricultural Economics. 15(2).

[6] Raha, S.K. (1975). Price Formulation of Selected Agricultural Products in Mymensingh Town. M.S. thesis, Department of Cooperation and Marketing, Bangladesh Agricultural University, Mymensingh. 
[7] Mannan, K. (1975). Seminar on Agricultural Marketing. First edition, Royal Library, Dhaka.

[8] Kohls, R.L. and Uhl, J.N.(2005). Marketing of Agricultural Products. Fifth Edition. Macmillan Publishing Co. Inc., New York.
[9] Rasel, D.R., Kale, P.N.,Patil, R.S. and Wagh, R.S.(1990). Effect of pre and post harvest treatments on biochemical composition and storage life of onion bulbs. Proceedings of the National Symposium on onion and Garlic. Held on June, 1990 at Dr.Y.S. Parmer University of Horticulture and Forestry, Solan, India. 